\title{
THREE BRIEF STUDIES: SLOVENE AND ALBANIAN
}

\section{Slovene enájst}

Bernard Comrie, in his contribution on the Slavic languages to the volume edited by J. Gvozdanović 1 (p. 766), reports a fact of particular historical interest. In presenting the forms and behavior of the 'teens amongst the numerals' Comrie states that two accentual patterns apply, an oxytone and a recessive, i.e. -nájst and ÚNITnajst. However, he points out that exceptionally in the case of ' 11 ' only enajst the oxytone occurs.

In the same volume, as it happens, I have mentioned (919-20) my observations 2 of the IE rule deleting ' 1 ' in complex phrases. It would seem that we may reconstruct enájst as *ná(d)es(e)t by this rule, and then only later a »normalizing « e(n)-would have been added. An interesting archaism matching OLith. liekas.

Since I am no Anglist I do not know what has been said on this, but contrary to German elf, zwölf (and apparently Speyer Gothic ainlif) English has eléven but twélve ${ }^{3}$. This should point to a post-Verner ${ }^{*} l i f(V) n$, but ${ }^{*}$ twólif under the same rule, preserved in this marginal insular dialect.

1 Jadranka Grozdanović ed., Indo-European Numerals. Berlin: Mouton 1992.

2 To the references cited add 'first', ZCP 45, 1992, 85-6. To D. Greene's report (502-4) I have some further comment to offer in the pages of Ériu.

3 I notice the following, which seem surprisingly inadequate and inattentive.

Chambers 1993 (normally compact, sound, and independent) $\mathrm{OE}$ en(d)le(o)fan : Go ainlif perh. (10 and) one left : Lat. linguere.

Merriam-Webster Collegiate ${ }_{10}$ (a popular reputable standard)

ME enleven < adj. < OE < end- a àn + leofan : lēon 'lend' : loan < ME lon < (OE līnn =) ON lān

Random House Unabriged ${ }_{2}$ (I must accept lapsed responsibility)

$M E$ elleven(e) - <ME len(d)en $<O E$ læ̈nan $<O E$ ellefne, endleofan : $O H G$ einlif $>$ elf, $O N$ ellifu :

LEAVE < leven < lǣan (caus.) : lăf 'remainder' : OHG leiban' $\rightarrow$ bleiben, ON leifa : Go. -laibjan.

The mention lā refers one to lave ${ }^{2}$.

Of course, in such dictionaries much must be omitted, and not only rich detail; but not the main features of shape and content of the word, while introducing dubious relevance.

From the forms cited we may recover the English series: end'leofan > en'leven (with removal or reduction of whatever seemed to be end-) $>$ el'lefne (by phonetic simplification) $>$ e'leven (further reduction) $>[\mathrm{I} \cdot \mathrm{I} \mathrm{g} \mathrm{g}]$ (modern values).

The following reconstructions are then imposed by known comparanda: *en-'lefan- < *aina-'liфana (Old English post-Verner intervocalic spirant voicing) $\leftarrow$ *aina+'liфa-na- (Germanic initial accent) $\leftarrow$ *'liфa(na-)(+'tehun) (loss of deletion rule for phantom 10, and survival of entailed inflexion or suffix) or *'lihua: OLith. liekas; versus *Numeral [du./pl.] + 'lih/ $/ \mathrm{k}^{\mathrm{w}} \mathrm{a}-\left(+^{\prime} 10\right)<{ }^{*}(1-$ deletion $)+$ Numeral $+1(\mathrm{e}) \mathrm{ik}^{\mathrm{w}}$-o- $+\mathrm{X}$. The last stage belonged to a more general PIE rule for NPs than just Numeral sequences; 11 is a precious relic. 


\section{Albanian kërcas and kërcej}

1. V. Orël in treating Alb. kërcas 'shout, resound' (1998: 180) subscribes to a reasonable conclusion, that we have an early borrowing from Slavic, but his account of the detail is inexact. The affricate $c$ is not the direct reflex of Slavic $c$. The primary modern result is Alb. s, e.g. porosis < poročiti 'order' (correct at Orël 338). Another instructive example is sorre 'crow' $<\mathrm{IE}{ }^{*} k^{w} \bar{e} r s n \bar{a}$, where Romanian cioară with its substratum borrowing as * $\check{c} \bar{r} \bar{a}$ in the Roman period shows us a relevant chronological benchmark; but this time Orël 399 , with many conflicting but unannotated references, essentially reproduces my argument but fails to say that we have here an initial labio-velar before the front vowel ${ }^{*} \bar{e}$. This Albanian evidence has consequences for Slavic crn $r$ as well as Baltic and Indic. Demiraj 355 will give much of the missing exact content, although both fail to report that the Dehnstufe (not just »a different ablaut«) of Albanian matches precisely the accent contrast of Slavic (=Baltic) vornna against ṽrnos. I add this to the interesting features linking Proto-Albanian to Balto-Slavic.

The reason, then, that kercas has a $c$ is simple, and recent. In position after $r$ or $l$ Alb. $s$ opening a stressed syllable routinely affricated; thus (conventional orthography) sjell 'bring' : përcjell 'accompany; swallow' (also përçlam 'ivy' < SCr. bršljan), pëlcas 'burst' but preterite plasa (not, with Orël 318 , "archaic $-c-\ll$ and never resulting from *-tj- which too gives a primary $s$ ).

Therefore, in southernmost Albania Çam preterite $3 \mathrm{sg}$. kritsi, reported by Pedersen 1895 , p. 16, but not noted by Orël, must have the $t s(=c)$ from the present stem, and therefore indirectly documents a preterite ${ }^{*} k r i s-i(3 \mathrm{sg}$.) etc. We now have a perfect match for Slavic *kričati. And the stressed vocalism of the present kërcas < ${ }^{\star} k r i s ́ a ́ t i$ - or better ${ }^{*} k r i c ́ a ́ c ́-V, 3 \mathrm{sg}$. kërcet $<{ }^{*} k r i c a t-i-t$ fits the stem of ${ }^{*} k r i c ̌ a-t i$ exactly.

Orël is concerned that Serbo-Croatian now has only 'warn' as the meaning of this etymon, and that Slovene could not be the source - I presume he considers it too far away. I think the pertinent conclusion must be that Slovene, a classic Bàrtoli lateral area, once again shows us an instructive conservatism. The semantics of our early Albanian borrowing are right.

2. kërcej is glossed by Orël (and others) as 'dance, jump'. He thinks the primary meaning is dance, and therefore traces it to ritual dance and badnjak. That may be, and I am no specialist in these matters. But Pedersen's Çam attests the alternant spelt këcej by Orël but këtséj by Pedersen; it means, as I have heard it in other Arbëresh and Arvanítika dialects, just 'jump'. Scutari in his Lessico for S. Costantino Albanese (of which he is a very talented and precise native) lists kcènj as 'saltare' and 'montare a cavallo'; 'ballare, giocare' is lùanj, the two senses in which I have heard it in many Arbëresh dialects.

Now if we consider kapërcej 'jump over', I find on consulting B. Demiraj 212 that he segments (without any result) as a derivative formation on the word kap '(an)- 
fassen, erreichen'. I think this is clearly mistaken. When we recall, as I believe I have shown, that an unstressed $\ddot{e}$ followed by a stressed $e$ results by contraction in $a$, we can segment kapërcej (or Scutari's kapircènj 'oltrepassare') as *kë-epër-cej. Here kë-< ${ }^{*} k^{\prime} m$ - (= Germanic $g a$-) I have claimed to be a preverb, often perfective. Now *kë-epërcej looks surely like a haplology form *kë-epër-kërcenj. The element épër (also épërm) 'upper' has been well discussed by Demiraj 168 (and deficientiy by Orël 89 with the wrong result), who accepts my 1981 explanation. Orël's error and Demiraj's mention of my erroneous 1965 comparison rest on their ignorance of my paper Acta Neophilologica (Ljubljana) (dedicated to Janez Stanonik) 25, 9-11, where I think I corrected and improved my (and our) old position. 4

The result is twofold: 1) Our compound means simply (perfectively) 'over-jump'; there is no trace of 'dance'. 2) The main verb and this compound are guaranteed by S. Costantino Albanese to the 15 th century in age by their attestation. This probably really means closer to a millenium, since we must count Arbëresh back to the time when Arvanítika separated from Epiros, if we regard Arbëresh largely as an Arvanítika colonization by emigration.

The only history I see clearly for kërcenj is 'jump', and nothing sacral. If the verb is related at all to kërc 'stump', and this to 'leg', 'shin', 'log, branch', it might seem closer to find a connexion with the matters of jumping.

Demiray, Bardhyl 1997. Albanische Etymologien. Amsterdam.

ORËL, Vladimir 1998. Albanian Etymological Dictionary. Leiden.

Pedersen, Holger 1895. Albanesische Texte mit Glossar. Leipzig.

SCUTARI, Pasquale 2002. Il lessico della parlata arbëreshe di San Costantino Albanese. Rende (CS): Università della Calabria.

III. Cesta and Language survival

Cesta, near Trubar's birthplace, is the site of an old Roman road. It is known that people moved there to settle after the burning of their village by Turks. Perhaps, in fact, they settled there because of the availability of stone for building on the site. The presence of Slavs here would date to a period long after the Romans.

The name Cesta 'street' appears to point to an old road, i.e. *strata, as in Strasse in the Ost-Tyrol Drau (Drava) Puster Tal valley or in Stratford or Stretton in Britain, where old stone ruins have been found. Cf. British Celtic Magnis in England (: Welsh mein 'stones', plural of maen), and Stanford, Stansted and Staines (near Heathrow), all to $\mathrm{OE}$ stān 'stone'.

4 My friend Janez has always pushed me to improvement. My life is a catalog of rejected positions relieved by victories. Many victories were inspired by friends. 
To convey cesta 'strata' to the Slavic presence we are led to an earlier Dolenska term. It is not probable that this was German speech here. It seems, then, that Dolenska Celtic may have been the intermediary. We thus conjecture that the Slovenes heard 'strata' still spoken Celtic much as in Resia (Friuli) a surviving *oseako was heard oso'ane < [oso-'iane] and understood. 5

If we try to conjecture what such Celts actually said, it seems likely that the word was not * kammi/en- 'a walk way, run way, path', 6 for that might have given *ponti- vel sim. Since cesta could carry the notation of cist- 'clean, clear', ${ }^{7}$ we might think of Welsh sarn 'highway' < 'strewn, spread' < ${ }^{*}$ tsar-no- $-\bar{a}<{ }^{*}$ str-n- $H-,{ }^{8}$ which of course is ultimately cognate with strata.

Povzetek

\section{TRI KRATKE ŠTUDIJE - SLOVENŠČINA IN ALBANŠČINA}

\section{Slovensko enájst}

Avtor izvaja slovensko enájst iz * $n a ́(d) e s(e) t$ in predpostavlja izbris števnika ' 1 ' že v indoevropskem prajeziku (izpričano tudi v starolitovskem liekas) in poznejšo »normalizacijo« $\mathrm{z}$ dodatkom $e(n)$.

\section{Albansko kërcas in kërcej}

Avtor vidi kot Orël v albanskem kërcas 'vpiti, razlegati se' zgodnji prevzetek iz slovanščine. V zlitniku $c$ vidi mlad razvoj starejšega $s$ v položaju za $r$ in $l$. Táko bi 3. edn. kërcet izhajala iz * kërset, to pa iz *kriśat- < *kricat-, kjer slednje popolnoma ustreza osnovi v slovanskem *krica-ti. Stari pomen 'vpiti' te slovanske osnove je ohranjen $v$ slovenščini kot obrobnem arealu.

Avtor izvaja kapërcej 'preskočiti' iz *kë-epër-cej, kjer je *kë- predpona, često za dovršnost (germansko ga-), épër pa pomeni 'zgoraj'. Rekonstruirano besedo dalje izvaja s haplologijo iz *kë-epërkërcenj, kjer kërcenj pomeni 'skakati' (ne tudi 'plesati') in je morda povezano s kërc 'štor'.

\section{Cesta in preživetje jezika}

Avtor razmišlja o možnem keltskem viru krajevnega imena Cesta.

5 Hamp, Eric P., I nomi di Resia. Ce Fastu? Sot la Nape 33, 1981, 11-16; also review of G. Frau, Linguistica 28, 1988, $141-7$.

6 Hamp, Eric P., On *sm in Gaulish and on the prehistory of *amminu. Romance Philology 28, 1974, 17-20.

7 Hamp, Eric P., Srbohrvaško cësta, slovensko cẹ́sta, Slavistična revija 31, 1983, 60-1.

8 Hamp, Eric P., Varia, Celtica 2, 1991, 33-47 \& 3. 